\title{
LAND COMPENSATION GAP FOR THE RESETTLEMENT OF THE INDIGENOUS COMMUNTIES IN BAKUN HYDROELECTRIC DAM
}

\author{
Wen-Chiat Lee* \\ Universiti Utara Malaysia \\ K. Kuperan Viswanathan \\ Universiti Utara Malaysia \\ Jamal Ali \\ Universiti Utara Malaysia
}

\begin{abstract}
Land compensation arising from relocation is a contested issue due to a lack of agreement on the levels of compensation by settlers. The effects of use values and non-use values on land compensation gap in Bakun Hydroelectric Dam in Sarawak, Malaysia are examined in this study. Multinomial Logit econometric estimators are used to examine the land compensation gap experienced by 379 settlers resettled as a result of the development project. The relationship between use values and non-use values in determining the land compensation gap is presented in the study. The gap is important in determining the satisfaction of settlers with regard to relocation. The findings can be used for better formulation of compensation policies in the case of large development projects.
\end{abstract}

Keywords: Land Compensation Gap; Resettlement; Bakun Hydroelectric Dam; Use and Non-Use Values.

\section{INTRODUCTION AND MOTIVATION FOR THE STUDY}

Land compensation for settlers relocated as a result of a development project such as the Bakun Hydroelectric Dam project is not a straight forward issue. Jehom (2008) found that settlers are often not adequately compensated. The inadequate compensation creates dissatisfaction among settlers as land is an integral part of their culture. Land provides a flow of multiple services to people dependent on land. These include livelihood opportunities, forests for hunting ground, ancestral burial grounds and other services (Sovacool and Valentine, 2011). Land is thus more than just an asset and requires closer attention in valuation activities. The settlers value the land as part of their

\footnotetext{
*Corresponding Author: Wen-Chiat Lee, School of Economics, Finance and Banking, Universiti Utara Malaysia, 06010 Sintok, Kedah, Malaysia. Email: wenchiat86@gmail.com
} 
life and land brings a broader meaning to their existence. Any attempts at compensation thus require a broader and richer understanding of land in the lives of the people involved in resettlement. Land is considered a part of the culture for the native people (Jehom, 2008) representing security and standing in society (Mahalingam and Vyas, 2011). Thus valuation of land requires the consideration of the non-use value aspects of land.

There are two contributions from this study. The first is with regard to the factors that determine land compensation gap. What factors determine the land compensation gap between the compensation awarded and what settlers consider adequate for the relocation? Understanding the factors will enable policy makers to reduce the land compensation gap and thus increase the satisfaction of the settlers. While there are numerous studies analyzing the resettlement impacts of dams, less attention has been paid to the study of determinants of land compensation gap in Malaysia. Only a few studies are available on the estimation of use values and non-use values in affecting land compensation gap. (Jehom, 2008; Swainson \& McGregor, 2008; Akca, Fujikura \& Sabbag, 2013; Fujikura \& Nakayama 2013) These authors used post project surveys and descriptive statistics to describe the compensation given. However, the empirical evidence making that connection between the compensation gap and the use and nonuse values is meager.

Second, this study contributes to the work on the land compensation policy by providing insights on reducing land compensation gap and enabling the progress forward on sustainable development in Malaysia. Most of the land compensations are not adequate because the compensation focused on use values alone (Swainson \& McGregor, 2008). Use values are like house values, land values which have prices operating on the market place. Non-use values are like social and cultural values which have no market values. This study provides a more comprehensive understanding of the determinants of land compensation gap by incorporating the use values and non-use values in determining total compensation.

\subsection{Overview of Bakun Hydroelectric Dam Case}

Bakun hydroelectric dam was first proposed in 1980s to exploit the potential of Sarawak Rivers. It is the biggest hydroelectric dam project in Southeast Asia. It has eight giant turbines. Bakun hydroelectric dam project has an installed capacity of 2400 megawatts and expected to generate electricity for about 30-50 years. The dam is on the Balui River, 37km upstream of Belaga in Sarawak, Malaysia. The surface area of the lake of Bakun Hydroelectric Dam is 695 sq km, about the size of Republic of Singapore (Ling, 2011). The costs of the project were estimated to be RM 15 billion though many argued that the costs are between RM25 to RM30 billion. The current cost of the project is RM7.2 billion (Banji, 2011a). Bakun Hydroelectric dam project is owned by federal government but is managed by Sarawak Hidro Sdn Bhd- a unit under the Ministry of Finance (Sibon, 2011). 
Figure 1: Location Map of Sungai Asap Resettlement Area

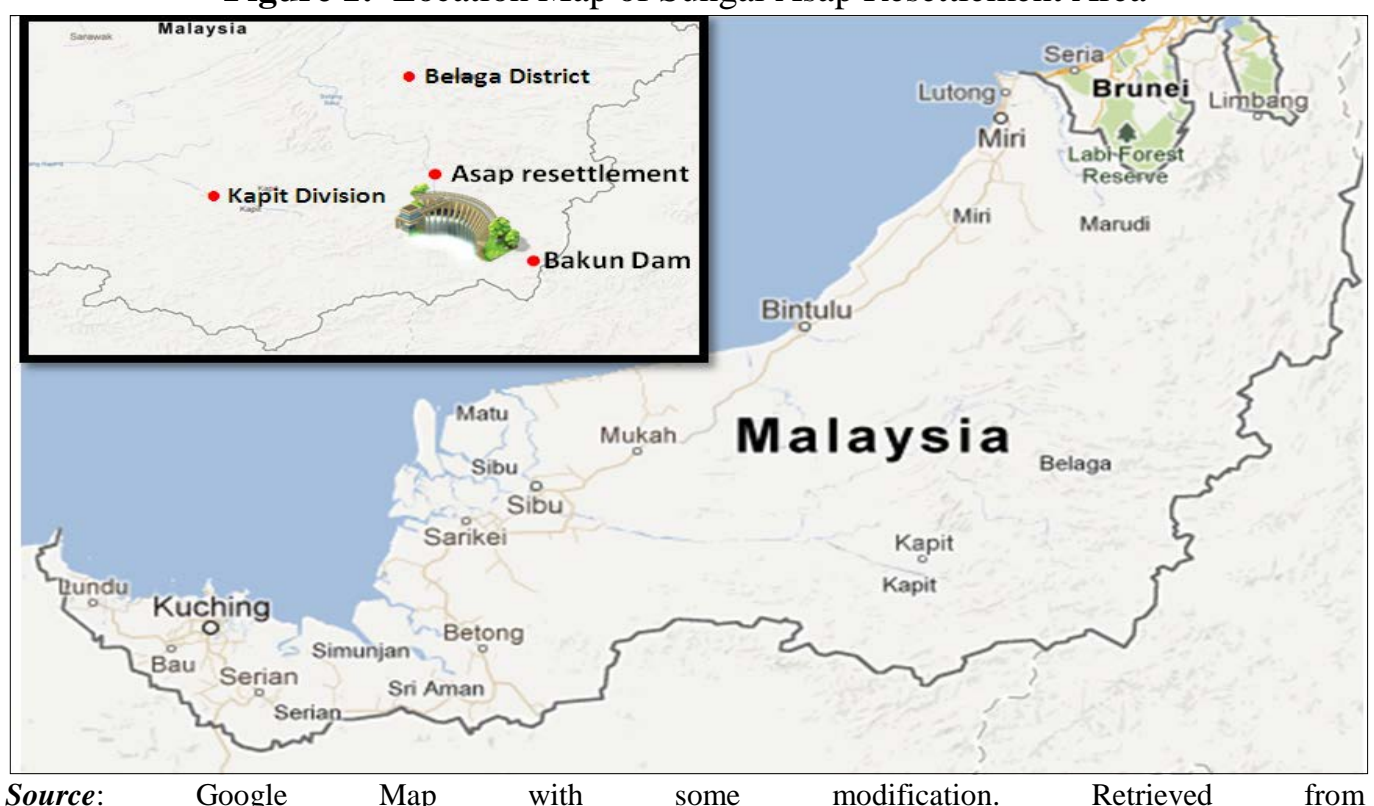

Source: Google Map with some modification. Retrieved from https://www.google.com/search?q=bakun+dam+map\&biw=1366\&bih=623\&source=lnms\&tbm=isch\&sa= X\&ved=0ahUKEwjWk5jqz9vKAhVGC44KHR9IBMAQ_AUIBygC\&dpr=1\#imgrc=ZvWQ4CmsRfWbTM $\% 3 \mathrm{~A}$

\subsection{Resettlement Caused by Construction of Bakun Dam}

The Bakun project has necessitated the relocation of 10000 people. They were moved to Sungai Asap. Sungai Asap resettlement area is about $30 \mathrm{~km}$ from the Bakun hydroelectric dam (Banji, 2011b).

Table 1: Population of the affected communities in year 1998

\begin{tabular}{ccc}
\hline \hline Ethic Group & Longhouse-Settlement & Population \\
\hline Kenyah & 4 & 4708 \\
Kayan & 8 & 3781 \\
Lahanan/Kajang & 1 & 535 \\
Ukit & 1 & 300 \\
Penan & 1 & 104 \\
Total & $\mathbf{1 5}$ & $\mathbf{9 4 2 8}$ \\
\hline \hline
\end{tabular}

Source: Sungai Asap District Office (2001)

According to the statistics released by Sungai Asap District Office the population affected by the Bakun Hydroelectric Dam in year 1998 is 9,428 people. There are basically five ethnic groups affected by the Bakun hydroelectric dam that are Kenyah, Kayan, Lahanan, Ukit, Penan. Out of these five ethnic groups, the indigenous population affected most is the Kenyah group of 4,708 people. This is followed by 
Kayan group of 3781 people, Lahanan group with 535 people, Ukit group with 300 people and Penan group with 104 people. This shows that the number of people affected by the Bakun hydroelectric dam project is large, affecting some $26.75 \%$ of the people in Belaga district in Sarawak.

\section{LITERATURE REVIEW}

The theoretical basis for the study is welfare theory. The utility of individuals are reduced as a result of resettlement. There is a difference in utility before and after resettlement.

Let $\mathrm{U}_{0}=$ Utility before resettlement

$\mathrm{U}_{1}=$ Utility after resettlement

Difference in utility = Utility before resettlement- utility after resettlement Difference in utility $=\mathrm{U}_{0}-\mathrm{U}_{1}$

Which, $\mathrm{U}_{0}>\mathrm{U}_{1}$

Figure 2: Utility before and after relocation

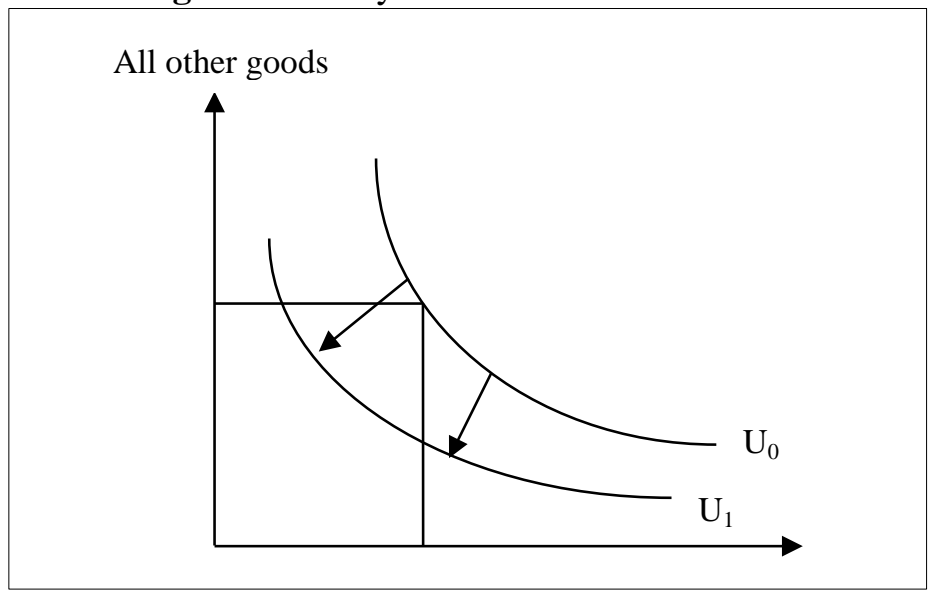

The compensation given by government is not able to bring $\mathrm{U}_{1}$ (utility after resettlement) back to $\mathrm{U}_{0}$ (utility before resettlement). To bring $\mathrm{U}_{1}$ equal to $\mathrm{U}_{0}$, the compensation packages needs to be large to include some important elements (non-use values) that are left out. The reduction in utility can also be expressed in indifference curves as shown in Figure 2.

In this study, we conceptualize utility/welfare as a function of use value variables, nonuse value variables and freedom and rights variables. Land compensation gap occurs when there is reduction in utility. If land compensation gap is fulfilled, there will be no 
difference in utility before and after resettlement. Thus, dissatisfaction towards compensation packages can be solved.

The risk and reconstruction model highlighted by Cernea (1997) stated the adverse resettlement impacts of the displaced communities. He highlighted the market impacts and non-market impacts resulting from resettlement in socio-economic impacts. It will bring impoverishment to settlers if not properly compensated from the use values and non-use values. One of the eight impoverishment impacts is landlessness. The displaced communities should have some rights towards compensation to improve the well-being.

World Commission on Dams (2000) stated that expropriation of farm land will result in loss of income or means of livelihood. Land is considered important to the settlers who are mostly rural farmers and rely on it for economic livelihood. Land compensation is important to increase the welfare of settlers.

The land compensation empirical literature stated that there are many problems documented in land compensation. A survey by Akca, Fujikura \& Sabbag (2013) found out that 99 resettled families in Ataturk Dam in Turkey claimed that compensation for the land is paid below market prices and many settlers owned less land areas than before resettlement. This caused the well-being of the settlers to go down.

Jehom (2008) claimed that major portion of land was not being reviewed for compensation in Bakun. There is a controversial issue of land compensation because the land rights owned by the settlers were not properly valued and little compensation on land was given. Many settlers did not understand how the land compensation was derived. Land values includes the cultural values and non-use values in the valuation for indigenous communities being resettled.

Swainson and McGregor (2008) did a study in Sungai Selangor dam in Malaysia and found that dissatisfaction with land compensation comes from cultural values (non-use values). The traditional land represents the identities and spiritual well-being are not included in compensation package because land compensation relies on more conventional quantitative development indicators of market value approach.

There is a connection between level of land compensation and satisfaction. Fujikura \& Nakayama (2013) who surveyed the post-project households regarding 10 resettlement programmes resulting from dam projects in Indonesia, Japan, Laos, Sri Lanka and Turkey found out that land compensation can lead to satisfaction. Thus, it is crucial to identify components that affect land compensation.

Non-use value reflects the common observation that people are more than willing to pay to preserve the resources that they will never use (Tietenberg, \& Lewis, 2009). Non-use values include non-market values. The non-use values are often not taken into consideration. However, most of the empirical studies just analyze the impacts of risk 
and reconstruction model on land compensation. Many of the studies done are after survey of the impacts brought by resettlement and description of land compensation is not adequate (eg. Jehom, 2008. Akca, Fujikura \& Sabbag (2013). Land compensation is very important as it encompasses cultural value and non-use values. A paper closer to the topic is Swainson and McGregor (2008). However, the empirical work on the effect of use value and non-use values on land compensation gap is still limited. There is a gap in empirical evidence on understanding the role of non-use values in affecting land compensation gap. Identifying land compensation gap is crucial. Understanding the factors affecting land compensation gap may shed some light on land compensation policy in reducing the land compensation problem in order to ensure sustainable development of Malaysia.

\section{DATA AND METHODOLOGY}

The data was collected using a standardized questionnaire and face to face interview with the settlers. In rural settings, face to face interviews provide a better platform for collecting data due to the lower level of education of household heads. The variables definition and measurement are presented in Appendix A. The interviews were carried out in Sungai Asap Resettlement Area, Belaga sub-district, Kapit Division over the period Sept 2012 to Dec. 2012. The data was collected for period of 3 months. The sample size is 379 is based on the recommendation of Sekaran \& Bougie 2009 for obtaining a representative sample from the population of 1639 households. The sample represents 23 percent of the population in the study area. Prior to the actual interviews, a pilot interview was carried out to test and validate the questionnaires. A total of 30 randomly selected settlers were interviewed for the pilot test.

The samples were chosen on the basis of a purposive sampling procedure. Purposive sampling is confined to obtaining information from specific type of people because they are the only ones who have the information (Sekaran \& Bougie, 2009).

The survey of head of household or wife was carried out over a period of three months from September to December 2012 using a standardized questionnaire. Interviews were carried out in the houses of the 15 villages located in Sungai Asap, sub district of the Belaga district, Sarawak.

Land compensation is defined as the compensation given to the affected settlers as a result of their land being taken away. Compensation of land has a value. The land value should include the future value generated for the residents and all the rights attached to the land (WCD, 2000).

The land compensation gap (acre) is measured using the expected land compensation by settlers (acre) minus the actual land compensation given by government (acre). There are five categories of land compensation gap: category 1 ( 0 to less than 7 acres), 
category 2 ( 7 acres to less than 12 acres), category 3 (12 acres to less than 27 acres), category 4 ( 27 acres to less than 37 acres) and category 5 (37 acres to 197 acres).

The variables are obtained from the pilot survey undertaken in the location of the study and WCD reports.

The dependent variable is the land compensation gap. The functional form of the compensation gap model is presented as follow:

Land Compensation Gap = f (use values, non-use values, socio-demographic variables)

Use values = Income from crops in cultivated lands and jungle resources, personal area of land, additional increment of land per year, house and level of infrastructures investment.

Non-use values $=$ importance of environmental quality value, importance of social value and importance of culture value, freedom and rights.

Multinomial logit regression model is used in this study because the land compensation gap (dependent variable) is a categorical variable.

The latent variable framework is used as we do not know what the actual value of compensation that a settler will prefer and thus the latent variable is used to represent his or her underlying land compensation value that will satisfy him/her.

Following the latent variable framework of Blanchflower and Oswald (2004) which assumed that for each category of land compensation gap, there is a latent variable which represents his or her underlying land compensation gap category. This latent variable is associated with use value and non-use value variables which are obtained from interview $\left(\mathrm{X}_{\mathrm{i}}\right)$. Let $\mathrm{Y}_{\mathrm{i}}^{*}$ represents this latent variable and assume that $\mathrm{Y}_{\mathrm{i}}^{*}$ is a linear function of $\mathrm{X}_{\mathrm{i}}$, thus,

$Y_{i}^{*}=\beta X_{i}+u_{i}$

Where,

$Y_{i}^{*}=$ underlying category of land compensation gap (unobservable)

$\mathrm{X}_{\mathrm{i}}=$ independent variables

The model assumes that the observed land compensation gap (Y) is related to the $\mathrm{Y}^{*}$ (which is unobservable) and is not assumed to be ordered. This assumption is needed because the ordered dimensions are not significant.

This study includes exponential function in the probability model of multinomial logit model to ensure the probabilities are non-negative values. Then, the exponential function is divided with the sum of exponential function to make the probabilities sum equal to 1 and equation (2) is obtained: 
$\operatorname{Pr}\left(y_{i}=m \mid x_{i}\right)=\frac{\exp \left(x_{i} \beta_{m}\right)}{\sum_{j=1}^{J} \exp \left(x_{i} \beta_{j}\right)}$

The model is estimated with the robust variance estimates (Huber/White/sandwich estimator of variance). The expected relationship of the variables associated with the land compensation gap is shown in table 2.

Table 2: Expected relationships of the variables associated with the land compensation gap

\begin{tabular}{lc}
\hline \hline \multicolumn{1}{c}{ Variables } & Expected Relationship \\
\hline 1. Kenyah ethnic & + \\
2. Kayan ethnic & + \\
3. Personal Land Area before relocation & + \\
4. Number of house before relocation & + \\
5. Infrastructure value before relocation & + \\
6. Environment value before relocation & + \\
7. Social value before relocation & + \\
8. Culture value before relocation & + \\
9. Rights to be informed before relocation & + \\
10. Rights to involve in compensation process & + \\
\hline \hline
\end{tabular}

\section{RESULTS AND DISCUSSION}

\subsection{Descriptive Statistics}

Table 3 presents the actual numbers of household selected from the population household. Uma/ Kampung Ukit has the highest percentage of sample to household (43.14\%) and followed by Uma Nyaving (42.53\%). Uma Kelap has the lowest percentage sample to household $(0 \%)$ due to the respondents not taking part in the interview process.

Table 3: Percentage of sample selected from household population

\begin{tabular}{llccc}
\hline \hline \multicolumn{1}{c}{ No. } & $\begin{array}{c}\text { Population } \\
\text { household }\end{array}$ & $\begin{array}{c}\text { Sample } \\
\text { household }\end{array}$ & $\begin{array}{c}\text { Percentage of sample to } \\
\text { household (\%) }\end{array}$ \\
\hline 1. & Uma Ukit & 51 & 22 & $43.14 \%$ \\
2. & Uma Lesong & 128 & 51 & $39.84 \%$ \\
3. & Uma Daro & 115 & 40 & $34.78 \%$ \\
4. & Uma Belor & 101 & 42 & $41.58 \%$ \\
5. & Uma Badeng & 197 & 52 & $26.40 \%$ \\
6. & Uma Nyaving & 87 & 37 & $42.53 \%$ \\
7. & Uma Kulit & 209 & 11 & $5.26 \%$ \\
8. & Uma Bakah & 223 & 53 & $23.77 \%$ \\
9. & Uma Balui Ukap & 84 & 3 & $3.57 \%$ \\
10. & Uma Bawang & 69 & 9 & $13.04 \%$ \\
\hline
\end{tabular}


Table 3: Percentage of sample selected from household population (con't)

\begin{tabular}{lccc}
\hline \hline \multicolumn{1}{c}{ No. } & $\begin{array}{c}\text { Population } \\
\text { household }\end{array}$ & $\begin{array}{c}\text { Sample } \\
\text { household }\end{array}$ & $\begin{array}{c}\text { Percentage of sample to } \\
\text { household (\%) }\end{array}$ \\
\hline 11. Uma Balui Liko & 68 & 13 & $19.12 \%$ \\
12. Uma Penan & 20 & 8 & $40.00 \%$ \\
13. Uma Lahanan & 89 & 8 & $8.99 \%$ \\
14. Uma Juman & 95 & 30 & $31.58 \%$ \\
$\quad$ Total & 1639 & 379 & $23 \%$ \\
\hline \hline
\end{tabular}

Note: The source of population household in year 1999 were obtained from Sungai Asap District Office.

Table 4 shows the descriptive statistics for variables used in the model.

Table 4: Differences between before and after resettlement

\begin{tabular}{ccc}
\hline \hline & Before resettlement & After resettlement \\
\hline Monthly income household (RM) & 645.51 & 470.90 \\
Land (acres) & 170.97 & 3 \\
House values (RM) & $26,107.69$ & $25,930.35$ \\
Number of houses (number) & 1 & 1 \\
\hline \hline
\end{tabular}

As seen from Table 4, there is a significant drop in land area available to the settlers after resettlement. Before resettlement, every household owned 170.97 acres of land on average. After the resettlement, every household was given 3 acres of land. Besides that, the monthly income has dropped drastically after resettlement. Before resettlement, the average monthly income per household is RM645.51. After resettlement, the average monthly income per household drops to a mere RM470.90. This indicates that the households suffer welfare loss and not compensated well after resettlement.

Table 5 shows the descriptive statistics for the variables used.

Table 5: Descriptive Statistics for the Variables

\begin{tabular}{llccc}
\hline \hline \multicolumn{1}{c}{ Variables } & Mean & $\begin{array}{c}\text { Standard } \\
\text { Deviation }\end{array}$ & Min & Max \\
\hline 1. Number of Other Members working & 1 & 1.48 & 0.000 & 10 \\
2. Monthly income before resettlement & 645.51 & 773.53 & 0 & 8000 \\
3. Monthly income after resettlement & 470.90 & 534.07 & 0 & 5000 \\
4. Age of respondent & 51 & 13.29 & 21 & 90 \\
5. Number of family members & 7 & 3.65 & 1 & 22 \\
6. Years of living in Bakun & 36 & 13.28 & 1 & 76 \\
7. Personal land area before resettlement (hectare) & 69.20 & 89.09 & 0 & 700 \\
8. Additional increment of land area per year & 10.47 & 28.33 & 0.000 & 300 \\
before resettlement (hectare) & & & & \\
9. Number of houses before resettlement & 1 & 0.14 & 1.000 & 2 \\
10. Value per house before resettlement (RM) & 26107.70 & 15261.41 & 0 & 70000 \\
\hline \hline
\end{tabular}


From Table 5, the mean age of respondents is 51 years old. The respondents have average family members of seven persons and number of others working members of one. The average monthly income before resettlement is RM645.51 and the average monthly income after resettlement is RM470.90.

Table 6 shows the descriptive statistics for freedom and rights variables.

Table 6: Descriptive Statistics for Freedom and Rights Variables

\begin{tabular}{lcccc}
\hline \hline & Mean & $\begin{array}{c}\text { Standard } \\
\text { Deviation }\end{array}$ & Min & Max \\
\hline 1. Freedom to be consulted during compensation process & 1.208 & 0.555 & 1 & 5 \\
2. Rights to be informed earlier during compensation process & 1.971 & 0.907 & 1 & 5 \\
3. Rights to involve in all stages of compensation & 2.103 & 0.889 & 1 & 5 \\
4. Freedom to prepare for changes in resettlement & 2.425 & 1.050 & 1 & 5 \\
5. Freedom of given choice to accept or reject final compensation & 1.488 & 0.843 & 1 & 5 \\
6. Freedom of community involvement in resettlement process & 2.565 & 1.179 & 1 & 5 \\
7. Freedom of community involvement in compensation process & 1.995 & 0.965 & 1 & 5 \\
\hline \hline
\end{tabular}

From Table 6, it is clear that the values of freedom and rights variables are well below the average of 2.5, suggesting that there is limited avenue for the settlers to voice their views regarding compensation.

\subsection{Regression of Land Compensation Gap Model}

Table 7 presents the results of the multinomial logit estimation for land compensation gap.

Table 7: Odds Ratio Multinomial Logit Estimation of Land Compensation Gap

\begin{tabular}{|c|c|c|c|c|}
\hline Variables & $\begin{array}{c}\text { Group } \\
2: 1\end{array}$ & $\begin{array}{c}\text { Group } \\
3: 1\end{array}$ & $\begin{array}{c}\text { Group } \\
4: 1\end{array}$ & $\begin{array}{c}\text { Group } \\
5: 1\end{array}$ \\
\hline DFemale & $\begin{array}{c}1.020 \\
(0.962)\end{array}$ & $\begin{array}{c}0.836 \\
(0.686)\end{array}$ & $\begin{array}{c}0.899 \\
(0.829)\end{array}$ & $\begin{array}{c}0.702 \\
(0.511)\end{array}$ \\
\hline DMarried & $\begin{array}{c}0.000 \\
(0.988)\end{array}$ & $\begin{array}{c}0.000 \\
(0.988)\end{array}$ & $\begin{array}{c}0.000 \\
(0.987)\end{array}$ & $\begin{array}{c}0.000 \\
(0.987)\end{array}$ \\
\hline DWidow & $\begin{array}{c}0.000 \\
(0.988)\end{array}$ & $\begin{array}{c}0.000 \\
(0.989)\end{array}$ & $\begin{array}{c}0.000 \\
(0.986)\end{array}$ & $\begin{array}{c}0.000 \\
(0.988)\end{array}$ \\
\hline DNotWorking & $\begin{array}{c}1.023 \\
(0.986)\end{array}$ & $\begin{array}{c}1.592 \\
(0.767)\end{array}$ & $\begin{array}{c}0.647 \\
(0.824)\end{array}$ & $\begin{array}{c}0.076 \\
(0.227)\end{array}$ \\
\hline DSelfEmployed & $\begin{array}{c}3.503 \\
(0.294)\end{array}$ & $\begin{array}{c}2.950 \\
(0.479)\end{array}$ & $\begin{array}{c}0.743 \\
(0.875)\end{array}$ & $\begin{array}{c}0.090 \\
(0.218)\end{array}$ \\
\hline DCashcrop & $\begin{array}{c}0.215 \\
(0.144)\end{array}$ & $\begin{array}{c}0.493 \\
(0.533)\end{array}$ & $\begin{array}{c}0.578 \\
(0.673)\end{array}$ & $\begin{array}{c}1.589 \\
(0.759)\end{array}$ \\
\hline DLabour & $\begin{array}{c}0.188 \\
(0.280)\end{array}$ & $\begin{array}{c}0.107 \\
(0.204)\end{array}$ & $\begin{array}{c}0.119 \\
(0.295)\end{array}$ & $\begin{array}{c}0.063 \\
(0.211)\end{array}$ \\
\hline DHunter & $\begin{array}{c}0.243 \\
(0.416)\end{array}$ & $\begin{array}{c}0.000 \\
(0.991)\end{array}$ & $\begin{array}{c}0.000 \\
(0.992)\end{array}$ & $\begin{array}{c}1.490 \\
(0.884)\end{array}$ \\
\hline DOtherJobs & 1.138 & 1.440 & 0.198 & 0.080 \\
\hline
\end{tabular}


Table 7: Odds Ratio Multinomial Logit Estimation of Land Compensation Gap (con't)

\begin{tabular}{|c|c|c|c|c|}
\hline Variables & $\begin{array}{c}\text { Group } \\
2: 1\end{array}$ & $\begin{array}{c}\text { Group } \\
3: 1\end{array}$ & $\begin{array}{c}\text { Group } \\
4: 1\end{array}$ & $\begin{array}{c}\text { Group } \\
5: 1\end{array}$ \\
\hline & $(0.931)$ & $(0.827)$ & $(0.009)^{* * *}$ & $(0.380)$ \\
\hline \multirow[t]{2}{*}{ Dfamilywork } & 0.520 & 0.581 & 0.546 & 1.155 \\
\hline & $(0.237)$ & $(0.378)$ & $(0.381)$ & $(0.849)$ \\
\hline \multirow[t]{2}{*}{ NumberWork } & 1.447 & 1.157 & 1.113 & 0.878 \\
\hline & $(0.074)^{*}$ & $(0.543)$ & $(0.683)$ & $(0.666)$ \\
\hline \multirow[t]{2}{*}{ Income } & 1.000 & 1.001 & 1.000 & 1.000 \\
\hline & $(0.905)$ & $(0.026)^{* *}$ & $(0.266)$ & $(0.747)$ \\
\hline \multirow[t]{2}{*}{ DChristian } & 1.171 & 1.112 & 2221824 & 1.368 \\
\hline & $(0.904)$ & $(0.938)$ & $(0.987)$ & $(0.854)$ \\
\hline \multirow[t]{2}{*}{ DIslam } & 1.001 & 0.000 & 8501975 & 0.000 \\
\hline & $(1.000)$ & $(0.989)$ & $(0.986)$ & $(0.994)$ \\
\hline \multirow[t]{2}{*}{ Education } & 1.235 & 1.304 & 1.247 & 1.159 \\
\hline & $(0.048)$ & $(0.018)$ & $(0.065)$ & $(0.270)$ \\
\hline \multirow[t]{2}{*}{ Age } & 1.016 & 1.044 & 1.008 & 0.996 \\
\hline & $(0.691)$ & $(0.333)$ & $(0.881)$ & $(0.952)$ \\
\hline \multirow[t]{2}{*}{ NumberPeopleInFamily } & 0.961 & 0.998 & 0.977 & 0.982 \\
\hline & $(0.428)$ & $(0.968)$ & $(0.716)$ & $(0.786)$ \\
\hline \multirow[t]{2}{*}{ DKenyah } & 3.858 & 5.374 & 36.174 & 20.554 \\
\hline & $(0.054)^{*}$ & $(0.028)^{* *}$ & $(0.009)^{* * *}$ & $(0.029)^{* *}$ \\
\hline \multirow[t]{2}{*}{ DKayan } & 3.372 & 2.811 & 29.139 & 6.976 \\
\hline & $(0.045)^{* *}$ & $(0.142)$ & $(0.009)^{* * *}$ & $(0.147)$ \\
\hline \multirow{2}{*}{ Years in Bakun } & 0.984 & 0.968 & 0.990 & 0.992 \\
\hline & $(0.682)$ & $(0.470)$ & $(0.862)$ & $(0.902)$ \\
\hline \multirow[t]{2}{*}{ Personal Land Area } & 1.005 & 1.004 & 1.007 & 1.011 \\
\hline & $(0.132)$ & $(0.262)$ & $(0.056)^{*}$ & $(0.002)^{* * *}$ \\
\hline \multirow[t]{2}{*}{ Additional increment land per year } & 0.998 & 1.016 & 1.009 & 1.012 \\
\hline & $(0.807)$ & $(0.117)$ & $(0.377)$ & $(0.660)$ \\
\hline \multirow[t]{2}{*}{ Number of house } & 0.206 & 0.242 & 1.847 & 0.932 \\
\hline & $(0.263)$ & $(0.298)$ & $(0.607)$ & $(0.956)$ \\
\hline \multirow[t]{2}{*}{ Price of 1 house } & 1.000 & 1.000 & 1.000 & 1.000 \\
\hline & $(0.733)$ & $(0.559)$ & $(0.539)$ & $(0.979)$ \\
\hline \multirow[t]{2}{*}{ Infrastructure } & 0.912 & 0.726 & 0.496 & 0.747 \\
\hline & $(0.742)$ & $(0.299)$ & $(0.031)^{* *}$ & $(0.418)$ \\
\hline \multirow[t]{2}{*}{ Environment Value } & 3.265 & 23.919 & 13.162 & 28.081 \\
\hline & $(0.152)$ & $(0.011)^{* *}$ & $(0.022)^{* *}$ & $(0.022)^{* *}$ \\
\hline \multirow[t]{2}{*}{ DHigh for Social Value } & 1.270 & 0.148 & 0.143 & 0.147 \\
\hline & $(0.847)$ & $(0.116)$ & $(0.118)$ & $(0.141)$ \\
\hline \multirow[t]{2}{*}{ Culture Value } & 1.188 & 4998119 & 0.327 & 0.794 \\
\hline & $(0.903)$ & $(0.990)$ & $(0.528)$ & $(0.910)$ \\
\hline \multirow[t]{2}{*}{ Freedom Consult } & 1.060 & 0.917 & 0.819 & 0.834 \\
\hline & $(0.853)$ & $(0.823)$ & $(0.668)$ & $(0.724)$ \\
\hline \multirow[t]{2}{*}{ Rights to be Informed } & 0.965 & 0.549 & 0.650 & 0.385 \\
\hline & $(0.878)$ & $(0.022)^{* *}$ & $(0.133)$ & $(0.004)^{* * *}$ \\
\hline \multirow[t]{2}{*}{ Rights to involve } & 1.570 & 1.229 & 1.224 & 2.101 \\
\hline & $(0.051)^{*}$ & $(0.427)$ & $(0.478)$ & $(0.014)^{* *}$ \\
\hline
\end{tabular}


Table 7: Odds Ratio Multinomial Logit Estimation of Land Compensation Gap (con’t)

\begin{tabular}{lcccc}
\hline \multicolumn{1}{c}{ Variables } & Group & Group & Group & Group \\
& $\mathbf{2 : 1}$ & $\mathbf{3 : 1}$ & $\mathbf{4 : 1}$ & $\mathbf{5 : 1}$ \\
\hline Freedom to prepare change & 1.145 & 0.978 & 0.887 & 1.100 \\
& $(0.489)$ & $(0.917)$ & $(0.590)$ & $(0.689)$ \\
Freedom of given choice to reject & 1.091 & 1.390 & $\mathbf{1 . 9 4 0}$ & 1.692 \\
& $(0.760)$ & $(0.272)$ & $(0.031)^{* *}$ & $(0.123)$ \\
Freedom of community involve resettlement & 1.274 & 0.817 & 1.303 & 1.272 \\
& $(0.160)$ & $(0.316)$ & $(0.204)$ & $(0.283)$ \\
Freedom of community involve compensation & 0.958 & 1.133 & 0.735 & 0.821 \\
& $(0.840)$ & $(0.600)$ & $(0.235)$ & $(0.474)$ \\
\hline \hline
\end{tabular}

Notes: The comparison group is group 1 . The values in parentheses indicate p-value. Asterisks $* * *, * *$ and $*$ indicate significant at $1 \%, 5 \%$ and $10 \%$ level respectively.

There are seven variables that are significant in group 4: group 1 in multinomial logit estimation for land compensation gap. There are education, ethnicity (dummy for Kenyah and dummy for Kayan), personal land area before resettlement, infrastructure investments before relocation, environmental quality value before relocation and freedom of choice to reject or accept the compensation given.

For socio-demographic variables, the probability for getting higher land compensation gap for those with higher education is higher compared with those lower education. Compared with other ethnics, probability of Kenyah to experience higher land compensation gap is higher. Compared with other ethnics, probability of Kayan to experience higher land compensation gap is higher. Ethnic representation also influences the land compensation gap. The Kenyah and Kayan form the majority of the settlers representing some 80 percent of the population. They therefore have a higher bargaining power in obtaining land compensation. Education plays a pivotal role in determining the level of land compensation gap. The values individual place on compensation is linked with their level of education and this probably also affects their ability to demand higher compensation.

For use value variables, the probability for getting higher land compensation gap for those with higher personal area of land before relocation is higher compared with those who had lower personal area of land before resettlement. The probability of obtaining a higher land compensation gap for those who perceived higher infrastructure investments quality before resettlement is lower than those who perceived lower infrastructure investments quality before resettlement.

For non-use value variables, the probability for obtaining a higher land compensation gap for those who perceived higher importance level of environmental quality value before relocation is higher compared with those who perceived lower importance level of environmental quality value. In all the cases for non-use variables, especially environment, the initial experience of the settlers with regard to the resources he/she has been accustomed to frames or shapes the gap expectation after resettlement. 
For freedom and rights variables, the probability for getting higher land compensation gap for those with higher freedom of choice to reject or accept the compensation given is higher compared to those with lower freedom of choice to reject or accept the compensation given.

\section{CONCLUSION}

This study examined the role of use values and non-use values on land compensation gap in Bakun hydroelectric dam in Sarawak, Malaysia. It is found that higher personal land area before relocation will increase the odd of getting higher land compensation gap. Therefore, land compensation policy should aim at giving more arable land for those settlers with high personal land area before relocation to reduce compensation gap. Also higher infrastructure value before relocation is more likely to have lower land compensation gap. This is consistent with theory in that the utility loss for settlers with larger land area will be higher due to resettlement compared to those with smaller land area before resettlement.

The non-use value findings from the study indicate that environmental values before relocation and freedom to accept or reject compensation are found to be significant in affecting land compensation gap. Those perceived higher environmental values before relocation are more likely to have higher land compensation gap. It is suggested that the Malaysian state authorities should include environmental value in land compensation. This implies that land compensation has a broader value because it encompasses environmental aspect such as forest, river and mountain for the indigenous communities to exercise their daily activities. Utility of settlers are affected by environmental values and must be considered in compensation.

It is also interesting to note that the existence of freedom of choice to reject or accept compensation is also related to the land compensation gap. Increase in freedom of choice to reject or accept compensation is likely to lead to higher land compensation gap. The existence of the freedom and land compensation gap relationship may assist policy makers in giving freedom for communities to discuss the compensation amount before asking the communities to reject or accept compensation.

Land compensation must take into account gaps in values such as use and non-use values settlers experience. These gaps depends on initial experience in their presettlement locations.

\section{ACKNOWLEDGMENT}

The author would like to thank the settlers at Sungai Asap and district office officials for their cooperation and assistance in collecting the household survey data. 


\section{REFERENCES}

Akca, E., Fujikura, R., \& Sabbag, C. (2013). Ataturk Dam resettlement process: increased disparity resulting from insufficient financial compensation. International Journal of Water Resources Development, 29(1), 101-108.

Banji, C. (2011a, January 16). RM100m for Belaga: Prime Minister announces eight mammoth projects which will directly benefit some 28000 villagers. The Sunday Post, pp.6.

Banji, C. (2011b, October 23). Subtle criticisms through poetry. The Borneo Post, pp.1. Blanchflower, G. D., \& Oswald, J. A. (2004). Well-being over time in Britain and USA. Journal of Public Economics, 88(7-8), 1359-1386.

Cernea, M. M. (1997). The risks and reconstruction model for resettling displaced populations. World Development, 25(10), 1569-1587.

Fujikura, R., \& Nakayama, M. (2013). The long-term impacts of resettlement programmes resulting from dam construction projects in Indonesia, Japan, Laos, Sri Lanka and Turkey: a comparison of land-for-land and cash compensation schemes. International Journal of Water Resources Development, 29(1), 4-13.

Jehom, W. J. (2008). Development and displacement: Kenyah-Badeng in Bakun Resettlement Malaysia. Unpublished PhD Dissertation, Universität zu Bonn, Bonn, Germany.

Ling, J. (2011, August 8). Bakun an eco-tourism goldmine. People in Sungai Asap resettlement area must work with SEB to tap its potential-Masing. The Borneo Post, pp.1.

Mahalingam, A., \& Vyas, A. (2011). Comparative Evaluation of Land Acquisition and Compensation Processes across the World. Economic and Political Weekly, 46(32), 94-102.

Sekaran, U., \& Bougie, R. (2009). Research Methods for Business: A Skill Building Approach. United Kingdom: John Wiley \& Sons Ltd.

Sibon, P. (2011, August 2). Bakun set to go commercial this Saturday. The Borneo Post, pp. 5.

Sovacool, B. K., \& Valentine, S. V. (2011). Bending bamboo: Restructuing rural electrification in Sarawak, Malaysia. Energy for Sustainable Development, 15(3), 240-253.

Swainson, L., \& McGregor, A. (2008). Compensating for development: Orang Asli experiences of Malaysia’s Sungai Selangor dam. Asia Pacific Viewpoint, 49(2), 155-167.

Tietenberg, T., \& Lewis, L. (2009). Environmental and natural resource economics. Boston, MA: Addison Wesley.

World Commission on Dams (2000). Dams and development: A new framework for decision-making. London, UK: Earthscan Publications Ltd. 


\section{APPENDIX}

Appendix 1: Definition and measurement of variables

\begin{tabular}{|c|c|c|}
\hline Variables & Definition & Measurement \\
\hline 1. Land compensation gap & $\begin{array}{l}\text { Expected compensation in } \\
\text { land minus actual } \\
\text { compensation in land }\end{array}$ & Acres \\
\hline 2. Personal area of land & $\begin{array}{l}\text { Area of land owned by } \\
\text { individual before relocation }\end{array}$ & Hectare \\
\hline $\begin{array}{l}\text { 3. Additional increment of } \\
\text { land per year }\end{array}$ & $\begin{array}{l}\text { Increment of area of land by } \\
\text { individual per year before } \\
\text { relocation }\end{array}$ & Hectare \\
\hline $\begin{array}{l}\text { 4. Value per house before } \\
\text { relocation }\end{array}$ & $\begin{array}{l}\text { Value per house owned by } \\
\text { individual before relocation }\end{array}$ & $\mathrm{RM}$ \\
\hline $\begin{array}{l}\text { 5. Number of houses } \\
\text { before relocation }\end{array}$ & $\begin{array}{l}\text { Number of houses owned by } \\
\text { individual before relocation }\end{array}$ & Unit of houses \\
\hline $\begin{array}{l}\text { 6. Level of infrastructure } \\
\text { investment }\end{array}$ & $\begin{array}{l}\text { Infrastructure (roads, } \\
\text { buildings, schools and shops) } \\
\text { values before relocation rated } \\
\text { by respondent }\end{array}$ & (1=low, 2=medium, 3=high) \\
\hline $\begin{array}{l}\text { 7. Environmental values } \\
\text { scale }\end{array}$ & $\begin{array}{l}\text { Perceived } \\
\text { environmental(river, } \\
\text { hills/mountains and forest) } \\
\text { values before relocation rated } \\
\text { by respondent }\end{array}$ & $\begin{array}{l}\text { (1=less important, } 2=\text { =medium } \\
\text { important, } 3=\text { =ery important) }\end{array}$ \\
\hline 8. Social value scale & $\begin{array}{l}\text { Perceived social value before } \\
\text { relocation rated by respondent }\end{array}$ & $\begin{array}{l}\text { (1=less important, } 2=\text { =medium } \\
\text { important, } 3=\text { =ery important) }\end{array}$ \\
\hline 9. Culture value scale & $\begin{array}{l}\text { Perceived culture value before } \\
\text { relocation rated by respondent }\end{array}$ & $\begin{array}{l}\text { (1=less important, } 2=\text { =medium } \\
\text { important, } 3=\text { =ery important) }\end{array}$ \\
\hline 10. Gender & Gender & (1=Male, $2=$ Female $)$ \\
\hline 11. Marital status & Marital status & (1=Single, $2=$ Married, $3=$ Others) \\
\hline 12. Employment status & Employment status & $\begin{array}{l}\text { (1=Unemployed, } 2=\text { Unable to work, } \\
3=\text { Full-time employed, } 4=\text { Part-time } \\
\text { employed, } 5=\text { Self employed) }\end{array}$ \\
\hline 13. Job & Job & $\begin{array}{c}\text { (1=Jungle resource collector, } \\
2=\text { Cash crop farmer, } 3=\text { Laborer at } \\
\text { oil palm plantation, } 4=\text { Hunter, } 5= \\
\text { Others })\end{array}$ \\
\hline $\begin{array}{l}\text { 14. Number of family } \\
\text { members working }\end{array}$ & $\begin{array}{l}\text { Number of family members } \\
\text { working }\end{array}$ & Number of individuals working \\
\hline 15. Income & $\begin{array}{l}\text { Income from crops and jungle } \\
\text { resources before relocation }\end{array}$ & RM \\
\hline 16. Religious affiliation & Religious affiliation & $\begin{array}{c}\text { (1=No religion, } 2=\text { Christian, } 3= \\
\text { Islam, } 4=\text { Bungan, } 5=\text { Buddhist, } 6= \\
\text { Taoist, } 7=\text { Others })\end{array}$ \\
\hline
\end{tabular}


Appendix 1: Definition and measurement of variables (con't)

\begin{tabular}{|c|c|c|}
\hline Variables & "Definition & "Measurement \\
\hline 17. Education level & Education level & $\begin{array}{c}\text { (1=No formal education, } 2=\text { Did not } \\
\text { complete primary school, } \\
\text { 3=Complete primary school, } 4=\text { Did } \\
\text { not complete lower secondary } \\
\text { school, 5= Complete lower } \\
\text { secondary school, 6=Did not } \\
\text { complete upper secondary school, } \\
\text { 7= Completed upper secondary } \\
\text { school(SPM/O-level/Equivalent), } \\
\text { 9=Certificate/Diploma/Equivalent, } \\
\text { 10=Bachelor degree/Equivalent, } \\
\text { 11=Master or PhD degree or } \\
\text { postgraduate/Equivalent, } 12=\text { Others }\end{array}$ \\
\hline 18. Age & Age & Years \\
\hline $\begin{array}{l}\text { 19. Number of people in } \\
\text { household }\end{array}$ & $\begin{array}{l}\text { Number of people in } \\
\text { household }\end{array}$ & Number of people \\
\hline 20. Ethnicity & Ethnicity & $\begin{array}{c}\text { (1=Kenyah, } 2=\text { Kayan, 3= Kajang, } \\
\text { 4=Ukit, 5= Penan and 6=Others) }\end{array}$ \\
\hline $\begin{array}{l}\text { 21. Years of living in Bakun } \\
\text { (before relocation) }\end{array}$ & $\begin{array}{l}\text { Years of living in Bakun } \\
\text { (before relocation) }\end{array}$ & Years \\
\hline $\begin{array}{l}\text { 22. Freedom to be consulted } \\
\text { in compensation process }\end{array}$ & $\begin{array}{l}\text { Perception of freedom to be } \\
\text { consulted in compensation } \\
\text { process }\end{array}$ & Likert scale 1-5 \\
\hline $\begin{array}{l}\text { 23. Rights to be informed } \\
\text { earlier in compensation }\end{array}$ & $\begin{array}{l}\text { Perception of rights to be } \\
\text { informed earlier in } \\
\text { compensation }\end{array}$ & Likert scale 1-5 \\
\hline $\begin{array}{l}\text { 24. Rights to be involved in } \\
\text { all compensation stages }\end{array}$ & $\begin{array}{l}\text { Perception of rights to be } \\
\text { involved in all compensation } \\
\text { stages }\end{array}$ & Likert scale 1-5 \\
\hline $\begin{array}{l}\text { 25. Freedom to prepare for } \\
\text { change in resettlement to } \\
\text { Sungai Asap } \\
\end{array}$ & $\begin{array}{l}\text { Perception of freedom to } \\
\text { prepare for change in } \\
\text { resettlement to Sungai Asap }\end{array}$ & Likert scale 1-5 \\
\hline $\begin{array}{l}\text { 26. Freedom of choice to } \\
\text { reject or accept the } \\
\text { compensation }\end{array}$ & $\begin{array}{l}\text { Perception of freedom of } \\
\text { choice to reject or accept the } \\
\text { compensation }\end{array}$ & Likert scale 1-5 \\
\hline $\begin{array}{l}\text { 27. Freedom of communities } \\
\text { to involve in resettlement } \\
\text { process }\end{array}$ & $\begin{array}{l}\text { Perception of freedom of } \\
\text { communities to involve in } \\
\text { resettlement process }\end{array}$ & Likert scale 1-5 \\
\hline $\begin{array}{l}\text { 28. Freedom of communities } \\
\text { to involve in } \\
\text { compensation process }\end{array}$ & $\begin{array}{l}\text { Perception of freedom of } \\
\text { communities to involve in } \\
\text { compensation process }\end{array}$ & Likert scale 1-5 \\
\hline
\end{tabular}

